\title{
E-learning as an Adaptation Strategy in Facing Covid- 19 Pandemic: A Case study on the 2018 and 2019- generation students of Post Graduate Sociology Department, University of Indonesia
}

\author{
Rifka Annisa ${ }^{1 *}$ Syarfina Mahya Nadila ${ }^{2 *}$ Syifa Andini Salsabila ${ }^{3 *}$ Syora Alya Eka \\ Putri $^{4 *}$ Hakiki Nurmajesti ${ }^{5}$ \\ 1,2,3,4,5 School of Social and Political Science, Sociology Department, University of Indonesia, Depok, Jawa Barat, \\ Indonesia \\ *Corresponding author.Email: rifkaannisahermanto@gmail.com \\ *All authors contributed equally to this work
}

\begin{abstract}
Covid-19 has resulted in social activities limitation by the Indonesia government, one of which is related to teaching and learning activities in the university. The Sociology Department of the University of Indonesia took steps by replacing usual lectures to online lectures or E-learning. Unlike usual lectures, E-learning suddenly challenges students to change their study habits. According to that statement, the research question was "how was the adaptation strategy undertaken by the Sociology Department of the University of Indonesia related to the teaching and learning process during the COVID-19 pandemic?" Thus, the aim of research is to apply the adaptation strategies, according to Smith's (1986) concept regarding an action plan at a certain period of time, group or the whole human being as an effort in steps with inside and outside their capabilities. E-learning concept by Horton (2010) is all forms of information and computer technology in creating learning experiences (formulated, organized, and created through internet devices). This research uses quantitative methods. The results show that lectures with the E-learning system were not effective with a score of 2.84 within a 1-5 scale. The Obstacles show the difficulties in the understanding materials, unstable signals, unsupported devices, and psychological problems. The E-learning barriers strategies commonly taken to overcome the obstacles are to ask colleagues for help, to search for the references using google searching engine, and to get social support from colleagues and families. The University of Indonesia E-learning system has not worked effectively yet. For this reason, contextual solutions are still needed to develop teaching and learning systems in order to remain effective despite the challenges during Covid-19 pandemic.
\end{abstract}

Keywords: E-learning, Covid-19, strategic adaptation, University of Indonesia

\section{INTRODUCTION}

Covid-19 pandemic has hit the world in the end of 2019 including Indonesia. The first Indonesia covid-19 case occurred in March 2020, and then the outbreak suddenly increases over times.

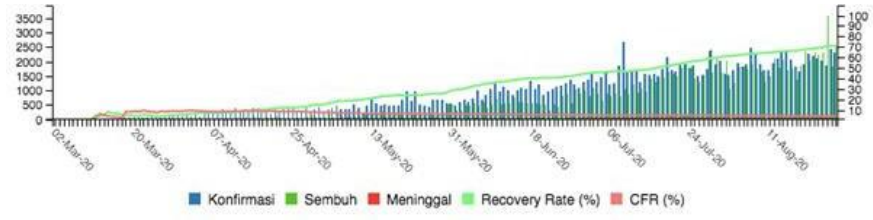

Figure 1. Covid-19 Spreading Data's.

Sources: https://covid19.kemkes.go.id 
The data taken from Indonesia Ministry of Health shows the positive case confirmation of the novel coronavirus increasing in March-August 2020. The facts show that the infection of covid-19 in Indonesia keeps getting worst, President Joko Widodo confirmed covid-19 pandemic to be a national disaster, as written in Presidential Decree Number 12 Year of 2020 (KEPRES No 12 Tahun 2020) about national disaster non-natural disaster of the corona virus disease outbreak 2019 (covid19) on April 2020[1].

The region mostly affected by covid-19 is DKI Jakarta, as the center of the outbreak. DKI Jakarta Government makes a very responsive policy to close all public places where people can gather such as School, Market, Office, Public Transportation etc., to prevent the worst possibility of citizens being infected with the virus. The fact that the number of people infected with covid-19 show an increase over times gives a huge impact on all the public sectors, one of which is the educational sector. After DKI Jakarta Government closed the school and changed all of class activities into E-learning [2], University of Indonesia released a Surat Edaran Rektor Universitas Indonesia Number: SE703/UN2.R/OTL.09/2020 to confirms a danger of covid19 spreading all over the University and ordered the civitas academica to delay or to cancel all programs, particularly the mass activity, one of which is class activity. To keep the academic program running well all the class activities are convert to E-learning gradually from March 19, 2020 to the end of semester on June 2020 and from September 2020 to the end of semester on January 2021 [3].

Referring to the University Indonesia chancellor policy release, the Dean of Social and Political Science Dr Arie Setiabudi Soesilo, MSc arranged the term and policy of E- learning by circular number: SE0157/UN2.F9.D/OTL.09/2020. The circular shows the Elearning works as an alternative learning using a digital platform by University of Indonesia called EMAS UI or ELearning Management System UI. Moreover, it is possible to use another meeting digital platform such as Skype for Business, Microsoft Team, Google HangOut, Google Classroom, Zoom and Digital Chat application such as Whatsapp, Line, and Telegram. All terms and conditions of the E-learning mechanism fully depend on the mutual agreement between lecturers and students. The Sociology Department as one of departments in the School of Social and Political Science (FISIP UI) replaced conventional lecture with E-learning. The different mechanism results in a lot of change and challenge not only to the lecture but also to the student. Unlike conventional lecture, E-learning suddenly challenges the students to change their learning habits. Then, the different ways of learning are the most interesting phenomenon to be studied. Therefore, the research question is what is the adaptation strategy undertaken by the Sociology Department of the University of Indonesia related to the teaching and learning process during the COVID-19 pandemic?

\section{LITERATURE REVIEW}

\subsection{An Adaptation Strategy}

Smith (1989) explains the concept of an adaptation strategy as an adaptation planning toward some phenomenon changing in a certain time, by certain groups of people or all human beings as a relatable effort to their capabilities from both inside and outside [4]. In determining the adaptation strategies, there are typical actors related to their social condition, by having a statement of the way they are thinking, planning, and doing.

In implementing an adaptation strategy, it is necessary to determine an intervention subject as people, systems, and sectors. Determining the intervention subject while creating an adaptation strategy makes it easier to implement the changes and to reorganize the adaptation within a predetermined time.

In this case, University of Indonesia determines the intervention subject as people consisting of students and lecture, a system in which classroom activities are converted to E-learning, and the sector, that is, a high education institution.

Intervention subject, according to Smith (1989) [5], can determined how an adaptation strategy is carried out by the actors; the actor here is public actors, initiated and likewise designed by the Indonesia Government at all structural levels and aimed at common needs, so that it organizes all of private actors consisting of individuals living in University of Indonesia environment.

University of Indonesia takes responsive adaptation after a national regulation of E-learning policy released by Indonesia Ministry of Education and Culture. The intervention time of an adaptation strategy took a period, firstly beginning on March 2020 to June 2020, and secondly beginning on September 2020 to January 2021. The basic purpose of the implementing an adaptation strategy is to protect all civitas academic, to reduce and to stop the spreading of covid-19 within the University of Indonesia environment.

\subsection{E-learning}

E-learning is the use of information and computer technologies to create learning experiences explained by Horton and Horton (2010) [6]. E-learning, as defined by Horton (2010), emphasizes on how learning experiences are formulated, organized, and created through an online learning system. E-learning was introduced by the University Illinois using a computer-based instruction called PLATO in 1960 [7]. Then, E-learning has been improved in a way to the sophisticated one along with the development of information technology. Nowadays, Elearning is marked as an indicator of the fifth generation Eeducation (study by a distance). Its implementation not only creates a solution to make study anywhere as possible but also has improved the way of learning going well 
during impossibility such as covid-19 pandemic

In the high educational institution, E-learning has been a massive development. Santoso (2018) states that there are more and continuous learning innovations made by universities to create and to use technology for learning activities. University of Indonesia has been implementing and improving the E-learning system as well. However, the process of implementation is still faced with obstacles such as not-supporting stakeholders and management, infrastructure, and facilities of the Learning Management system (LSM) [8].

Rusman in Hanum (2013) states the four characteristics of E-learning: (1) interactivity, the well supporting communication tools, both directly like chatting and indirectly like discussion forum or mailing list; (2) independency, flexible time provided, place, instruction and teaching materials to make a studentcentered learning model; (3) accessibility, the accessible learning sources online such as open access journals, Ebooks, and other learning material bank data; (4) enrichment, the learning activities, such as enrichment of learning material presentation, allowing the use of technological devices such as video streaming and animation training for the student and lectures [9].

Effendi (2005) adds that in E-learning using, it is necessary to formulate a concrete strategy to set a standard quality in terms of successful implementation of Elearning system, and that strategy is useful for (1) clarifying the training and learning objectives, (2) understanding the needed resources, (3) creating synergy among all the learning participants referring to mutually agreed objectives, (4) measuring possibly the success point of learning system [10].

\section{METHODS}

This research used a quantitative approach with quantitative data collection techniques by distributing questionnaire. The questionnaire was distributed through the Google Form by Whatsapp broadcasting massages in April 17-18, 2020. The sampling method used non-random sampling. Hence, the result only applied to the sample level. The questionnaires were distributed to 50 names collected out of 94 names of post graduate students in Sociology department of University of Indonesia in 2018 and 2019. The descriptive analysis applied to this research elaborated E-learning phenomenon and enriched observation by the researchers.

\section{RESULTS AND DISCUSSIONS}

After the process of data collection, the brief explanation of respondent profile is given, and then the questionnaire results are aligned with the concept of E-learning as an adaptation strategy.

\subsection{Respondents Profile}

In this research, majority respondents $(50 \%)$ come from Sociology of Social Policy Development (KPS) Class of 2019 and the rest come from Sociology Class (48\%). Most respondents $(30 \%)$ works as freelancer and the rest work as Civil Servant (PNS), and full-time student with average of $22 \%$. Then, for the marital status, most students $(74 \%)$ are not married and married (26\%). During covid-19 pandemic, $62.5 \%$ of students work from home

\section{Respodent's Specialization}

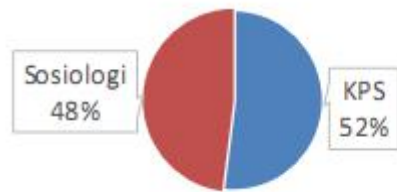

- KPS

- Sosiologi

Figure 2. Respondent Specialization

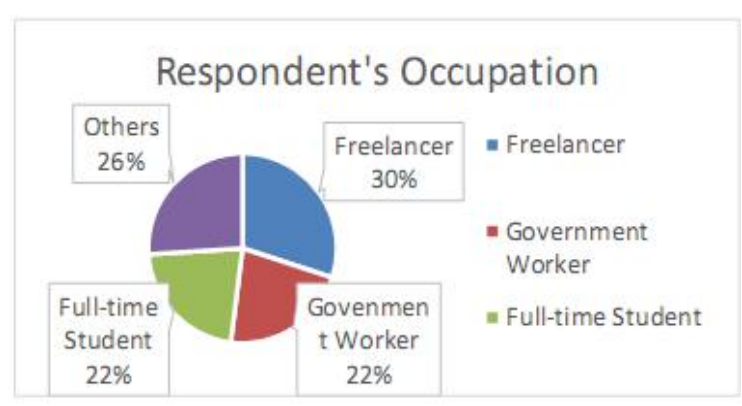

Figure 3. Respondent's Occupation

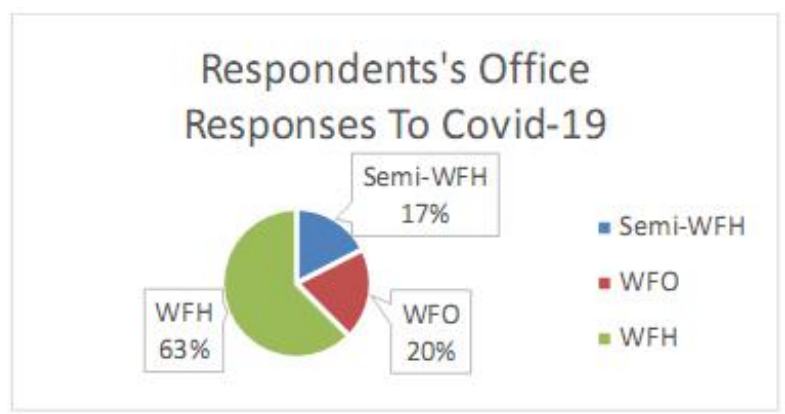

Figure 4. Respondent's Office Responses to Covid-19

\subsection{E-learning As an Adaptation Strategy}

University of Indonesia responded to the Indonesia Government policy toward the covid-19 pandemic by implementing E-learning as an adaptation strategy. Elearning has been implemented not only at the university of Indonesia as a public actor, but also by private actors such as students and lectures. 
Covid-19 pandemic suddenly changes all kinds of communal activities, one of which is teaching-learning activities. E-learning faces many obstacles in its implementation: less prepared condition, difficulty students and lecturers find in learning that in turn result in ineffective learning activities. The assessment of questionnaire data result in 50 names of respondents obtaining average score of 2.87 within $1-5$ in the term of effectiveness learning, indicating that the learning is less effective. Hence, E-learning is ineffective for many reasons: unstable internet connection, poor communication between students and lectures, and other psychological problems during the disruption due to the covid-19 pandemic. The student's unpreparedness in facing Elearning is shown with $82 \%$ of respondents tending to prefer classroom activities considered as more effective and interactive.

The four aspects of the E-learning effectiveness explain that interactivity, independency, accessibility, and enrichment should be included while implementing Elearning. Referring to that statement, the data shows the interactivity between lectures and students using Whatsapp $(22.3 \%)$. However, using online chatting application, both lecturers and students still face an obstacles such as misunderstanding on the lecturer's learning directions $(28.7 \%)$, distance bringing difficulties in direct communication between lectures and students (23.5\%), learning time disorientation related to the availability of lecturer $(13.2 \%)$, and difficulty in contacting the lecturers.

The aspect of interactivity is shown by the relationship not only between private actors (lectures and students), but also between the students. The data shows $26.5 \%$ of respondents expect compensation in the lecture assignment target, $52.1 \%$ respondents are claiming both paper and presentation, and individual or groups assignment are too hard in the displacement time during pandemic. The reasons elaborating why the heavy condition happens are: firstly, the differences of productive online time between them; secondly, the college life culture putting communal activities such as discussion and coordinating group assignment in the university. In facing the difficult conditions, students still create their own adaptation strategy by connecting, bonding, and communicating online to each other. It can be seen from the data of asking the classmates for help (19.3\%), searching for information using google (googling) (18.7\%), and opening E-library access called remote-lib.ui (10.7\%).

The second aspect is independency, meaning that it is a student-centered learning. University of Indonesia developed learning website in order to support the aim. There are Emas UI and lib.ui. However, in the beginning of E-learning implementation, the learning model used was still teacher-centered learning. The lecturer still plays a crucial role while class activities are running. The data shows that $22.1 \%$ of respondents consider that lecturing time becomes the self-agreement while conducting a class. The fact shows that $62.5 \%$ of respondents work from home, but most of students still attempt to adapt to the class so that a double task should be dealt with, as shown by $15.7 \%$ of respondents claiming and $10 \%$ claiming to have less time to take a rest. Therefore, a balance created in the independency aspect related to how students play is shown by $16.7 \%$ respondents converting the pressure to the hobbies and $14 \%$ taking a short break.

The third aspect is accessibility, meaning the inclusiveness to get an equal access to the learning process and procedures. The accessibility draws an important attention in this research, and the data shows that accessibility becomes the first obstacle in which students can leave the class from the beginning of, because they do not have access to get along the with E-learning activities. The most useful devices are laptop, handphone, and PC. $16.2 \%$ of respondents have a problem related to nonsupporting device such as a broken laptop. The second obstacle is internet connection, most students get an unlimited free internet access in the university areas, but when E-learning implemented they should learn from home, so that they should provide the internet access themselves, as shown by $19.9 \%$ of respondents wanting the university to takes a part in providing free internet credits to pay their internet bills in order to attend the Elearning class activities.

The last is the enrichment aspect. In this research, the enrichment intended explains the learning process during E-learning implementation, the way of learning material presented using video streaming, animation, and simulation in which $19.9 \%$ of respondents want a variety of learning models in attending E-learning class. About $26.4 \%$ of respondents claim that journal articles and books are the most useful reading sources, $24.8 \%$ claim that YouTube videos are attractive material sources, and $24.8 \%$ think Powerpoint slides are attractive too. For the digital meeting application students are familiar with Skype for Business, Microsoft Team, Google HangOut, Google Classroom, Zoom and Digital Chat application such as Whatsapp, Line, and Telegram. Even though the learning media are quite varying, $16.2 \%$ of respondents admitted that they still have difficulty in understanding the learning material delivered online.

From these four aspects of an effective E-learning, it can be concluded that the implementation of E-learning in the Postgraduate School of Sociology Department of University of Indonesia is considered as less effective. The ineffectiveness of this E-learning add some psychological problems such as anxiety, over worries, and fear. However, with all the obstacles, the authentic embedded traits of Sociology Postgraduate UI that they have a communal culture that can be one of the best adaptation strategy during covid-19 pandemic. 


\section{CONCLUSION}

From this research, it can be concluded that although University of Indonesia has implemented a responsive adaptation strategy right after the Indonesia's Ministry of Education and Culture released the E-learning policy, the implementation of it still faces many obstacles and shows ineffectiveness and exclusiveness.

From the conclusion above, the following recommendation can be given. For E-learning to run effectively, it should think of creating online learning facilities such as internet credits for students, make an evaluation to reduce the miscommunication between lecture and students, fix the class time schedules, and provide digital technologies simulation training to make both students and lecturers to be tech-literate.

\section{ACKNOWLEDGMENT}

This work was supported by Postgraduate Sociology Department University of Indonesia and the 2018 and 2019 generation-students of Postgraduate Sociology Department.

\section{REFERENCES}

[1] Effendi, Empy \& Zuang, Hartono. (2005). Elearning Konsep dan Aplikasi. Jakarta: Penerbit Andi Yogyakarta.

[2] Hanum, N. 2013. Keefektifan E-learning sebagai media pembelajaran (studi evaluasi model pembelajaran e- learning SMK Telkom Sandhy Putra Purwokerto).
Jurnal Pendidikan Vokasi, 3 (1) Universitas Negeri Yogyakarta. (https://doi.org/10.21831/jpv.v3i1.1584)

[3] Horton, William and Horton, Katherine. 2003. ELearning Tools and Technologies: a consumer's guide for trainers, teachers, educators, and instructional designers. USA: Wiley Publising. Inc, page 12-24

[4] Smith, Bhatti, Menzhulin, Beniof, Campos, Jallow, Rijsberman, Budyko, Dixon. 1996. Adapting to Climate Change, An International Perspective. New York: Springer- Verlage.

[5] The kinds of adaptation strategies by Smith et al. 1999; the definition by IPPC, McCarthy et al. 2001

[6] (https://www.cs.ui.ac.id/index.php/akselerasi-elearning-dan-online-education-di-tanah-air/) Accesses in July 26, 2020.

[7] (http://www.leerbeleving.nl/wbts/1/history_of_elea rnin g.html) Accesses in July 26, 2020.

[8] (https://bnpb.go.id/berita/presiden-tetapkancovid19- sebagai-bencana-nasional) Accesses in August 3,2020 .

[9] (https://www.kompas.tv/article/71235/resmianies- baswedan-tutup-sementara-semua-sekolah-didki-jakarta). Accesses in August 3, 2020.

[10] (https://www.ui.ac.id/cegah-penyebaran-coronaui- terapkan-sejumlah-kebijakan/) Accesses in August 3, 2020. 